\title{
Search for Barents: Evaluation of Possible Burial Sites on North Novaya Zemlya, Russia
}

\author{
JAAPJAN J. ZEEBERG, ${ }^{1}$ PIETER M. FLOORE, ${ }^{2}$ GEORGE J.R. MAAT ${ }^{3}$ and JERZY H. GAWRONSKI ${ }^{2}$
}

(Received 14 May 2001; accepted in revised form 19 November 2001)

\begin{abstract}
Three cairns on northernmost Novaya Zemlya identified as possible rock-pile graves by Russian investigators in 1977 and 1988 were located and inspected for human remains. These cairns are in the area visited by Dutch seafarers between 17 and 22 June 1597, after their wintering on Novaya Zemlya, and may contain the body of Willem Barents. Barents and one of his crewmen died on 20 June 1597 while the winterers were on landfast ice close to shore. Previous research on Spitsbergen and contemporary reports on the efforts of 16th and 17th century Dutch seafarers to prepare a Christian grave led us to conclude that the deceased probably were buried on the beach, possibly in a shallow grave or a snowbank. Inspection of the area indicates that this grave probably was destroyed by high $(5+\mathrm{m}$ asl) wave run-up during storms, cryogenic erosion, and animals (polar bear, fox). None of the cairns, or any of several other prominent rock piles in the $\sim 180 \mathrm{~km}$ long search area, contained human remains or had lichen growths that would indicate construction $\sim 400$ years ago ( $>2 \mathrm{~cm}$, Rhizocarpon sp.). Cairns were not reported by the Dutch in 1594-98, and most of those encountered on northern Novaya Zemlya probably date from explorations after ca. 1860, when the region north of $\sim 76^{\circ} \mathrm{N}$ became accessible in a warming, post-Little Ice Age climate.
\end{abstract}

Key words: Novaya Zemlya, Willem Barents, historical archeology, Arctic exploration, cairns, burial rituals, cartography

RÉSUMÉ. Trois cairns situés aux confins septentrionaux de la Nouvelle-Zemble et identifiés en 1977 et 1988 par des chercheurs russes comme pouvant signaler des amas de pierres funéraires ont été localisés et ont fait l'objet d'une inspection en vue de déterminer s'ils renfermaient des restes humains. Ces cairns se trouvent dans la région visitée par des navigateurs néerlandais entre le 17 et le 22 juin 1597, après leur hivernage en Nouvelle-Zemble, et ils auraient pu contenir le corps de Willem Barents. Ce dernier et un membre de son équipage périrent le 20 juin 1597, alors que les hivernants se trouvaient sur la glace près du rivage. Des recherches antérieures sur le Spitzberg et des rapports contemporains sur les efforts des marins néerlandais des XVI ${ }^{\mathrm{e}}$ et XVII ${ }^{\mathrm{e}}$ siècles en vue de préparer une sépulture chrétienne nous amènent à la conclusion que les défunts ont probablement été enterrés sur la plage, voire dans une tombe peu profonde ou un amoncellement de neige. Un examen du site indique que cette tombe a probablement été détruite par un assaut puissant (+5 m ASL) des vagues au cours de tempêtes, par l'érosion cryogénique et par les animaux (ours polaire, renard). Aucun des cairns, et aucun des autres amas de rochers bien visibles situés dans la région de l'étude, qui s'étendait sur une longueur d'environ $180 \mathrm{~km}$, ne renfermait de vestiges humains ou n'affichait une croissance lichénique qui aurait indiqué une construction remontant à près de 400 ans (> $2 \mathrm{~cm}$, Rhizocarpon sp.) Les Néerlandais n'ont pas rapporté la présence de cairns entre 1594 et 1598 et ceux que l'on a retrouvés en Nouvelle-Zemble septentrionale datent probablement des explorations qui eurent lieu après environ 1860 , quand la région située en gros au nord du $76^{\circ}$ de latit. N. est devenue accessible dans le contexte d'un réchauffement climatique survenu au petit âge glaciaire.

Mots clés: Nouvelle-Zemble, Willem Barents, archéologie historique, exploration arctique, cairns, rites funéraires, cartographie

Traduit pour la revue Arctic par Nésida Loyer.

[20 June 1597] When the sun was southeast [ 7 a.m.], Claesz Andriesz began to be extremely sick, whereby we perceived that he would not live long. The boatswain came into our scute and told us in what case he was and that he could not long continue alive; whereupon Willem Barents spoke: "I guess with me too it will not last long." Yet we did not judge Willem Barents to be so sick, because we sat talking one with the other and spoke of many things, and Willem Barents studied the map that I had made during our voyage (and we had some discussion about it). Then he put away the map and said "Gerrit, can you give me something to drink," and he had no sooner drunk or he was taken with so sudden a qualm, that he turned his eyes in his head and died presently. We had no

\footnotetext{
${ }^{1}$ Department of Earth \& Environmental Sciences (M/C 186), University of Illinois at Chicago, 845 West Taylor Street, Chicago, Illinois 60607-7059, U.S.A.; present address: Netherlands Institute for Fisheries Research (RIVO), P.O. Box 68, 1970 AB IJmuiden, The Netherlands; jzeebe1@uicalumni.org

${ }^{2}$ Amsterdams Archeologisch Centrum, University of Amsterdam, Nieuwe Prinsengracht 130, 1018 VZ Amsterdam, The Netherlands

${ }^{3}$ Department of Anatomy, Leiden University Medical Center, P.O. Box 9602, 2300 RC Leiden, The Netherlands

(c) The Arctic Institute of North America
} 
time to call the master out of the other boat to talk to him; he died before Claesz Andriesz, who died shortly after him. (De Veer, 1598: log entry for 20 June 1597)

\section{INTRODUCTION}

The narration of the voyages of navigator Willem Barents to Novaya Zemlya, written by crewman Gerrit de Veer (De Veer, 1598, in English edition of Beke, 1853), is a document uncommon in the annals of Dutch maritime history, yet equally remarkable as a testimony of daily life. The Dutch under the leadership of Barents attempted for three consecutive years $(1594,1595$, and 1596) to sail to the Indies (east Asia) by way of the North Pole. This ambitious endeavor stranded off Cape Spory Navolok (Fig. 1a,b) in August 1596, when the ship was beset and nipped by ice within $14^{\circ}$ latitude of the Pole. On an escarpment of the windswept Arctic desert, overlooking the frozen sea, the explorers constructed a cabin, which appeared on their maps as het Behouden Huys (the Saved House). Inside, the men were sheltered and for ten months awaited the passing of winter. The ship remained in the solid embrace of the ice, and on 14 June 1597, the Dutch took to sea in the two open and adapted boats of their vessel. Barents had been ill during the last months of the wintering and died on 20 June, probably from the effects of scurvy. He may have been buried on the coast of northern Novaya Zemlya, although it is commonly assumed that his body was disposed of at sea (Hacquebord, 1995; Van der Werf, 1998).

Dutch Arctic exploration was economically motivated, but it also served to satisfy a scientific curiosity. Willem Barents was the first to produce a representation of the European Arctic based on verifiable observations, which extended beyond the information provided by Renaissance translations of Ptolemy and Pliny the Elder. Many misconceptions and hypothetical coastlines were systematically eliminated. North Russian seafarers (called Pomors) told how the open sea would extend past Novaya Zemlya and possibly throughout the entire Arctic. The north cape of Novaya Zemlya, from which the jump into the unknown was to be made, was given the significant name "Cape Desire" (in Russian, Mys Zhelaniya) in 1595. Despite the setback of three failed expeditions, interest continued in the Netherlands for exploring the northern seaway, which, in contrast to the southern route, had not been monopolized by the United Dutch East India Company. The States-General did indeed discuss resuming the Arctic navigation and sent Henry Hudson north in 1609 (with a well-known result).

The Arctic voyages between 1593 and 1597 are documented by the publications of Jan Huygen van Linschoten (1601), who participated in those voyages in 1594 and 1595 , and Gerrit de Veer, whose account was published in 1598 and 1599 in Dutch, Latin, French, and German. This book partly compensates for a distinct lack of primary documents from the third voyage-possibly because they were lost or none were kept. Van Linschoten delivers the only known contemporary criticism of the works of his young colleague. In his Voyage or navigation round by the north (1601:2), Van Linschoten refers to De Veer's journal as "the tract printed of that voyage" and writes:

I made my notes at the time that, whatever it is I wrote down, occurred, and not only after the voyage had been completed. And to avoid the impression that I later added something or left something out, I have stuck to the original style of the journal.

From this, one may infer that De Veer presented an adaptation of notes, in the first place notes taken by himself, possibly adding data collected by Barents. The winter camp discovered in 1871 on Cape Spory Navolok, northeast Novaya Zemlya, provided the material link between the account and its historical context. Many objects recovered from the Saved House in 1871 and 1876 have been returned to the Netherlands (Braat et al., 1998).

Preservation in its original context of a complex of finds from the era of the northwest European expansion is rare and often restricted to shipwrecks. A site like the Saved House offers a wealth of index materials from the earliest stage of Dutch global expansion. This complex illustrates the transition from the Middle Ages to Early Modern Time, previously documented by iconographic observations. Archaeological excavations of the Saved House on Cape Spory Navolok in 1993 and 1995 demonstrate that the cabin's floor plan was based on a "Golden Section" building ratio. This plan indicates that the ship's carpenter, following the loss of the ship, fell back on established cultural principles to optimize the crew's chances of survival (Gawronski, 1997). Excavations of 16th to 18th century settlements on Spitsbergen demonstrate that the Arctic climate has preserved many archeological traces that would have been lost in wetter and warmer climates (Hacquebord, 1981; Kist, 1981; cf. Floore et al., 1999). Comparison of remains retrieved from Cape Spory Navolok in the 1870s with those retrieved in 1993 and 1995 suggests that corrosion rates and decay have accelerated in the past century. This acceleration is due in part to climate changes associated with the "Little Ice Age," which ended in northern Russia after about 1860 (e.g., Zeeberg, 2001). Hence, there is a need to complete research into archaeological remains in the Arctic as thoroughly as practicable.

Following identification of possible rock-pile graves on northern Novaya Zemlya, we searched three times, in 1993, 1995, and 1998, for the double grave implied by Gerrit de Veer in his account of the voyage. Russian archaeologist Dmitri Kravchenko claimed to have discovered three graves, potentially holding the bodies of Willem Barents and Claes Andriesz (Kravchenko, 1981, 1983). A fourth grave, discovered by Russian investigators on the beach of Ivanov Bay in 1988 (Salikov, 1997), was identified 

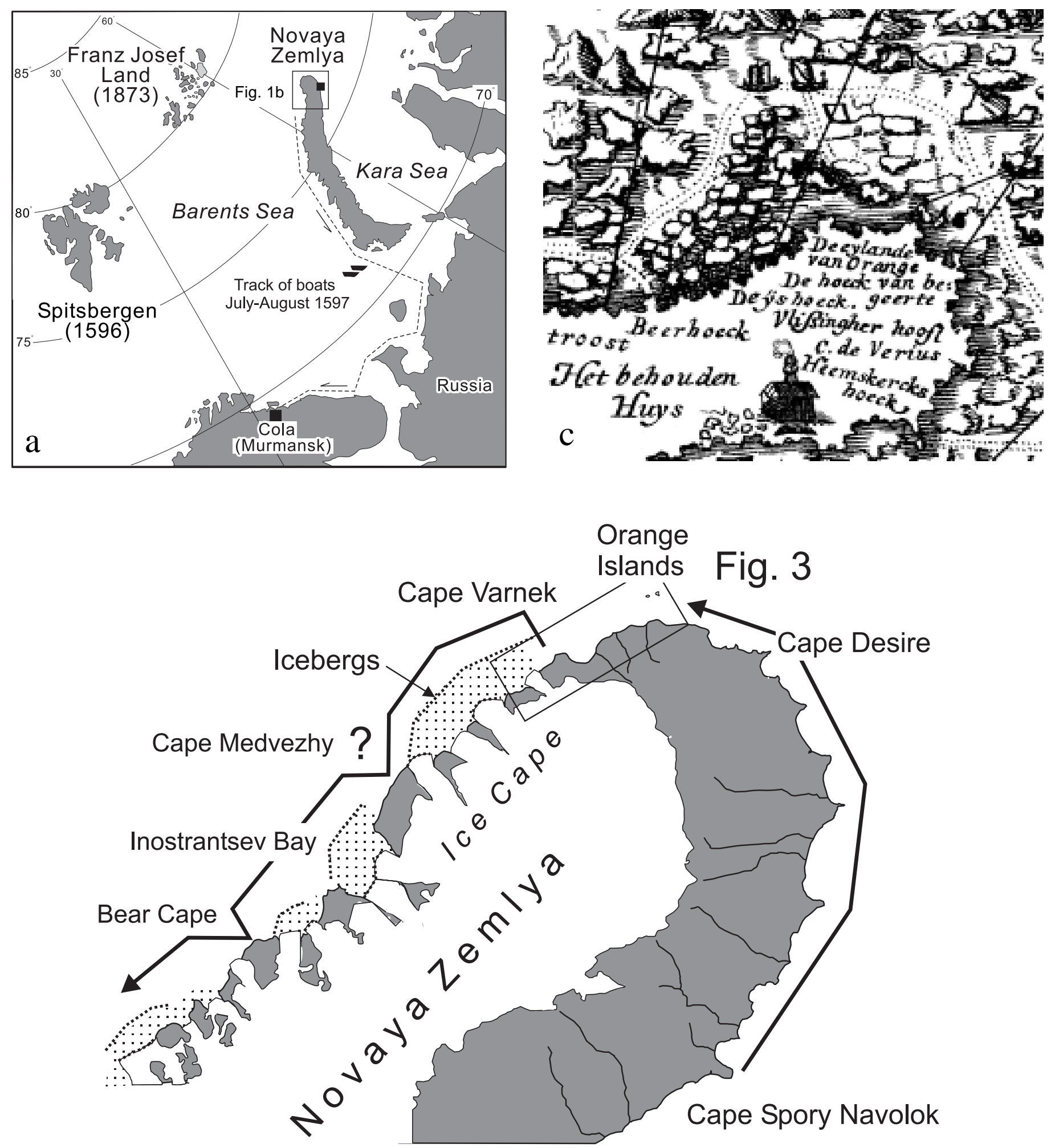

b

0

$40 \mathrm{~km}$

FIG. 1. (a) Location of northernmost Novaya Zemlya. (b) Location of sites discussed in text. (c) Inset of Barents' map from De Veer (1598): The increased density of sea ice near the north cape of Novaya Zemlya may reflect iceberg calving. The track plotted on this map suggests that the Dutch maneuvered around the iceberg area before they continued along the coast. 


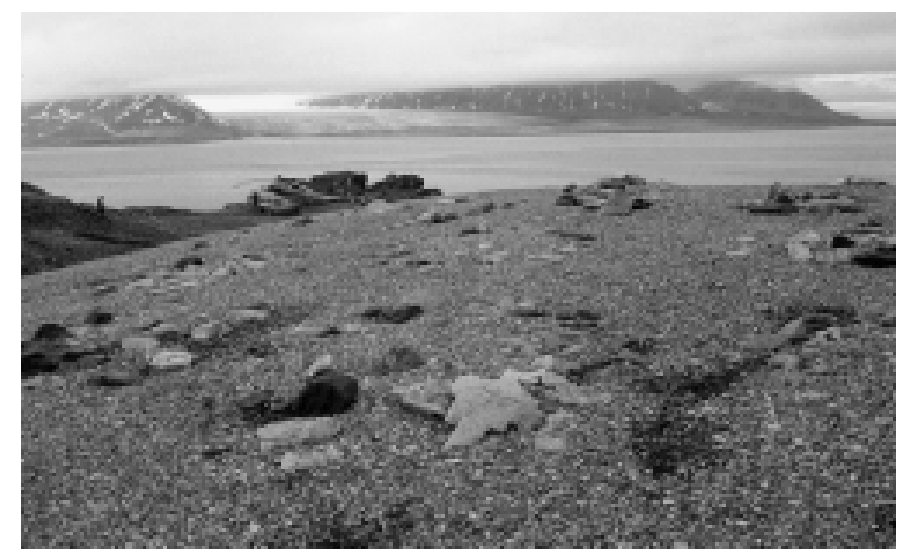

FIG. 2. Whaler graves at Bellsund, east coast of Recherchefjorden, southwest Spitsbergen, on a raised beach $18-20 \mathrm{~m}$ asl. Beach construction of pebbles and gravel is similar to that of beaches on north Novaya Zemlya. Photo by J. Zeeberg.

during a helicopter survey of Novaya Zemlya's northern cape in August 1993. Surveys on foot in 1995 and 1998 were designed to investigate those parts of the northern coast visited by the winterers in June 1597 , a total of $\sim 180 \mathrm{~km}$ between Cape Carlsen (Fig. 3) and Inostrantsev Bay (Fig. 1c). The search for his grave is a tribute to Barents and his companions, and retrieval of remains would yield information on the physical condition, diet, and clothing of these Arctic seafarers (e.g., Maat, 1981; Beattie and Geiger, 1987; Maat and Floore, 1997; Arneborg et al., 1999). This paper explains why we think that Barents and Andriesz were buried in a durable grave on northwestern Novaya Zemlya. It also reports on our inspection of the most probable burial locations, including those first identified by Kravchenko (1981, 1983).

\section{ASSUMPTIONS}

\section{A Grave or a Burial at Sea?}

Gerrit de Veer summarily reported the event of Barents' death but omitted a description of the burial, and the fate of the bodies remains undescribed. In the case of previous deaths, the corpses were interred with some ceremony. During the wintering, the "sicke" man died on the evening of 26 January 1597, and Bible passages were read. The next day, psalms were sung before all went outside, despite the tremendous cold, to bury the deceased "in seven feet of snow" (De Veer, 1598: log entry for 26 January 1597). Investigations into the burial rituals of 17 th-century Dutch seafarers on northwest Spitsbergen, where ground conditions are comparable to those of Novaya Zemlya, indicates that the dead would be taken on land for burial according to Christian principles, i.e., facing east (Hacquebord, 1981; Maat, 1981; Werner, 1990). The deceased were placed in improvised wooden coffins and buried on promontories in shallow ( $<0.6 \mathrm{~m}$ deep) graves, which were marked with a cross. Boulders were collected

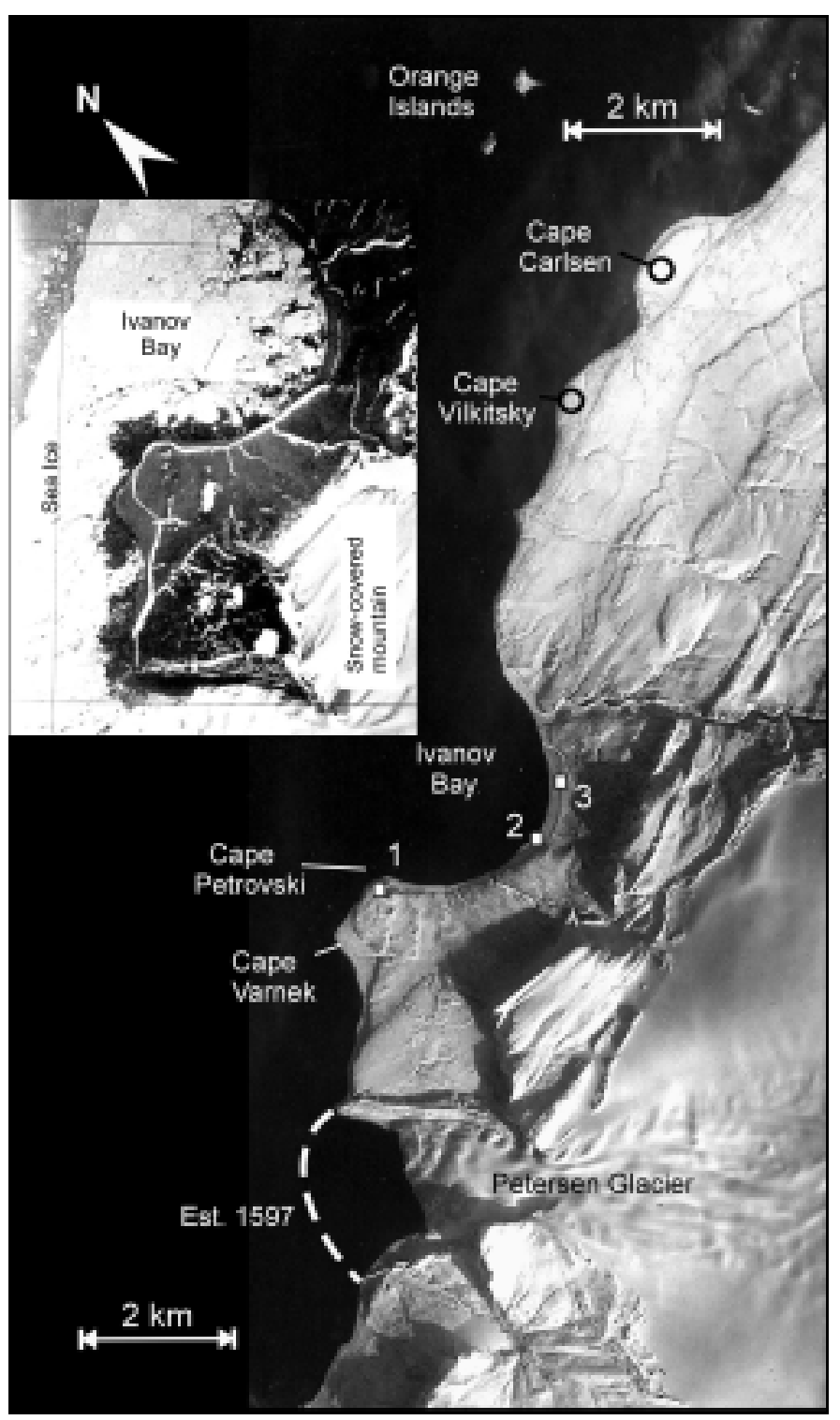

FIG. 3. Corona (KH-4A) satellite image of northernmost Novaya Zemlya, showing study areas around Ivanov Bay. Cape Carlsen is Novaya Zemlya's north cape $\left(77^{\circ} \mathrm{N}\right)$. Petersen Glacier is the first glacier of the Ice Cape region (Fig. 1b). Inset shows sea ice around Cape Petrovski/Varnek on an air photo from 25 July 1952. White lines in this photograph indicate snowbanks around a 5-30 m high escarpment.

from adjacent areas and piled on the coffins to protect the corpses from scavenging animals (Fig. 2). Only when it was impossible to reach land would a man be "buried" at sea, because this was against the beliefs of these often very religious seafarers (Hacquebord, 1981). Burial at sea was a hygienic measure during voyages in tropical waters, where decomposition was rapid.

The Dutch at the instant of Barents' passing were on fast ice close to dry land and would most likely have brought their dead ashore. On 17 June 1597, the drifting ice threatened to crush the sloops, and De Veer wrote: "In this ultimate distress, with nothing to lose, I, being the lightest of all, endeavored to take a hawser onto the fast ice, crawling from one ice floe onto the next" (De Veer, 1598, 
$\log$ entry). Fast ice, or landfast ice, is a belt of sea ice frozen to the shore and hence immobile. Barents and Andriesz were carried onto the ice, and the boats were hoisted out of the water; then the sick were put back in the boats. This improvised camp was at or close to the beach, because the men collected driftwood for a fire to melt tar and repair the boats. Several men searched the inland area for birds and eggs. In the morning of 20 June, Barents and Andriesz died. On 21 June, the wind swung into the southeast and blew the drifting sea ice away, thus clearing the sea and enabling the mariners to continue their homeward voyage. Hence, it appears likely that Barents and Andriesz were buried ashore. This view is consistent with a passage from Rerum et Urbis Amstelodamensium Historia (1614), which was written by contemporary Amsterdam chronicler Johannes Pontanus in 1609, and likely gives the personal account of one of the survivors of the wintering:

Then, on the 5th of July died Jan Fransz van Haerlem, cousin of Claes Andriesz. Again the ice drifted forcefully in our direction. Six crew went ashore once more to gather some firewood for cooking, and having peacefully placed him, just like the previous, in a grave of ice, shining more beautiful than marble, they returned to the sea. (cited in Maat and Floore, 1997)

Barents' grave may have survived if the men made an effort to carry the corpses ashore and build a cairn over them. During the 1594 expedition in the Yugor Strait, the Dutch had witnessed polar bears destroying graves and scavenging on the dead, and they probably took precautions to spare their leader a similar fate. However, De Veer omitted any mention of the burial and this suggests that the survivors were uncomfortable with the procedure followed and that the dead were left in an improvised grave, perhaps on the ice or in a snowbank.

\section{The Length of a Mile}

The navigation documented by Gerrit de Veer involves a set of longitudinal distances measured in "German miles" and latitudes taken with an astrolabe or cross-staff whenever the position of the sun or a star could be determined. To assess the accuracy of De Veer's latitudinal observations and assist our surveys on Novaya Zemlya, Van der Werf (1998) simulated the positions of the sun, stars, and planets and compared those with actual measurements recorded by Barents and De Veer. These measurements are accurate within $15^{\prime}$ to $20^{\prime}$ - as accurate as the instrumentation would allow. The meridional position of the boats is estimated from the distance covered while maneuvering along the coast and through sea ice. These distances are reported in German miles, which must be converted to kilometres before a position can be found on current maps. One German mile probably measured 3725 Amsterdam fathoms of $1.698 \mathrm{~m}$, equalling $6.3 \mathrm{~km}$ (Verhoeff, 1983). On Barents' posthumously published map of the Arctic, it is noted: "Duytsche mylen; 15. in een graedt" [German miles: 15. in a degree]. Van der Werf (1998) observes that, if the calculation is based on the earth's circumference of $39960 \mathrm{~km}$, each one-degree rotation would cover a circumferential segment of $111 \mathrm{~km}$, and that a German mile thus equals $111 / 15$ or $7.4 \mathrm{~km}$. However, the earth's circumference was first fixed with significant precision (3.4\% too small) by Snellius (Willebrord Snell, 1591-1626), through triangulation, in the early 17 th century.

The Greek astronomer Eratosthenes calculated the earth's circumference in 200 B.C., using trigonometry. A fragment from De Veer's account (De Veer, 1598: log entry for 24 January 1597) shows that Barents and De Veer applied classical trigonometry to calculate meridional distances.

One has to understand that a degree [in these regions] is not as large as at the equator. At the equator, one degree spans 15 [German] miles, but when one deviates from the equator, whether to the north or to the south, degrees become smaller. Thus, at 76 degrees northern latitude, where we were wintering, a degree covers not 15 [German] miles but 3.66 [German] miles.

This text is consistent with the polar projection of their maps, in which latitudes form circles around the poles and longitudes intersect at the poles. By definition, a circle's circumference is $2 \pi$ times the radius of that circle. By taking the cosine of $76^{\circ}$ multiplied by the earth's radius at the equator, one will obtain the radius of that latitudinal circle. Eratosthenes calculated the circumference of the earth at the equator as $46250 \mathrm{~km}$. Had De Veer used the value of this "ancient," the length of his German mile would be $8.6 \mathrm{~km}$. If the Dutch used $6.3 \mathrm{~km}$ as the value of one mile, it would appear that they calculated the circumference of the earth as $34020 \mathrm{~km}$.

Comparison of the distances documented by De Veer with true distances does not yield a finite measure for a mile either. On 16 June, sailing from Cape Zhelaniya to the Orange Islands, the sloops covered a distance of eight German miles or $(8 \times 6.3) 50 \mathrm{~km}$. The distance of 8 miles, in reality, covers $24 \mathrm{~km}$, assuming the sloops' trajectory ran some distance offshore. What, then, is the origin of this $26 \mathrm{~km}$ disparity? The estimate of speed may have been affected by changing wind direction (south to northwest), maneuvering around ice floes, or setbacks due to the coastal current, adding $26 \mathrm{~km}$. There is a powerful current from south to north along the western coast of Novaya Zemlya (Litke, 1835, cited in Beke, 1853; cf. Pfirman et al., 1997). The speed of this current is $\sim 1 \mathrm{knot}(1.8 \mathrm{~km} / \mathrm{hr})$ at northwestern Novaya Zemlya (Arctic Pilot, 1959; Pilot of the Barents Sea, 1995). The boats reached Cape Troost [Cape Consolation, now Cape Utesheniya, Russkaya Gavan'] on 23 June, thus having covered about $150 \mathrm{~km}-$ with a "fair breeze from the south"- since ca. 0300 on 22 June. The distance recorded by De Veer for this stretch is 30 miles, suggesting that 1 mile equals about $5 \mathrm{~km}$ (cf. Maat and Verlaan, 2001). Here, the coastal current apparently was taken into account or was compensated by a 


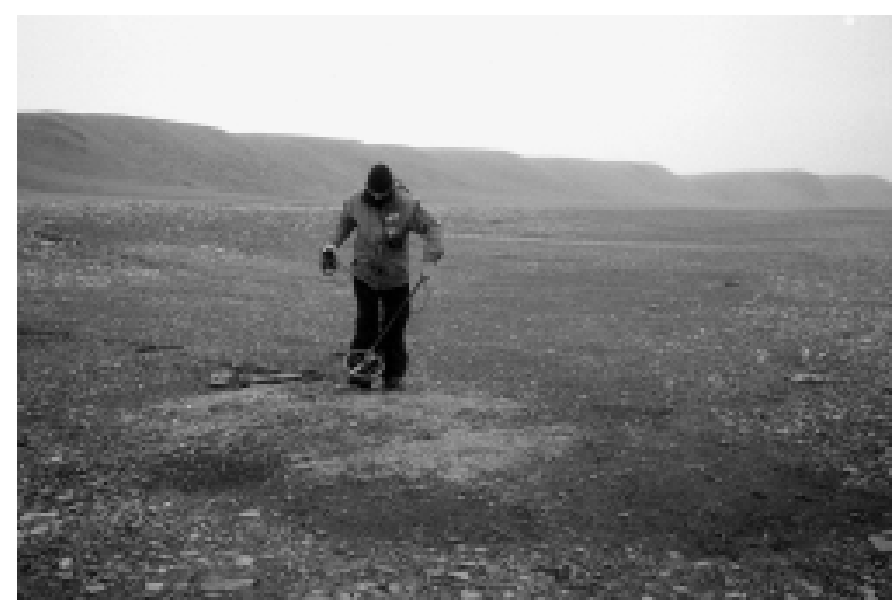

FIG. 4. Inspection with a metal detector of a moss growth in Inostrantsev Bay. Novaya Zemlya is a nutrient-deficient arctic desert and moss is a good indicator of bone material, a source of phosphates. A grave, therefore, may be recognized from large moss growths. Photo by J. Zeeberg.

fortunate gale. Thus, the historical data indicate that a German mile equals $6.3 \mathrm{~km}$, but the measurement of a mile along the Novaya Zemlya coast may be off by as much as $3 \mathrm{~km}$.

\section{Area Description and Methods}

The location of the landing of the Dutch after Barents' death is estimated by reconstructing the progress of the boats from the Orange Islands, as described by Gerrit de Veer. The distance covered from the Orange Islands before the boats tied to ice floes is five German miles (25$35 \mathrm{~km}$, depending on the value given to the German mile). Surrounded by sea ice and unable to continue, the boats then drifted eastward with the wind and ocean current towards Cape Varnek, the western promontory of Ivanov Bay (Fig. 3). The strong easterly current was apparent during our surveys of the area in 1995 and 1998 from the drift of icebergs released by calving glaciers of "Ice Cape." A similar field of icebergs probably forced the winterers to seek refuge ashore, and it may have been depicted in the map of northern Novaya Zemlya (Fig. 1c). A reconstruction of glacier extent in northern Novaya Zemlya shows that glacier calving fronts have formed a more or less continuous barrier over a distance of $30 \mathrm{~km}$ (Zeeberg and Forman, 2001). The name IJshoeck ('Ice Cape' or 'Ice Quarter') therefore appears to apply to this entire region. All events between 17 and 21 June 1597 occurred in the area between Ice Cape (Fig. 1b) and Cape Carlsen (Fig. 3), on both sides of Ivanov Bay.

The coasts of northern Novaya Zemlya are easily accessed via beaches 100-500 m wide, which have undulating ridges of loose gravel and large, rounded cobbles, and end in an escarpment over $5 \mathrm{~m}$ high. The escarpment is covered in many places by steep, partly glacierized snowbanks, which have retreated under 20th century warming. Retreat of the snowbanks released a large number of skeletal remains, which have been identified as whale,

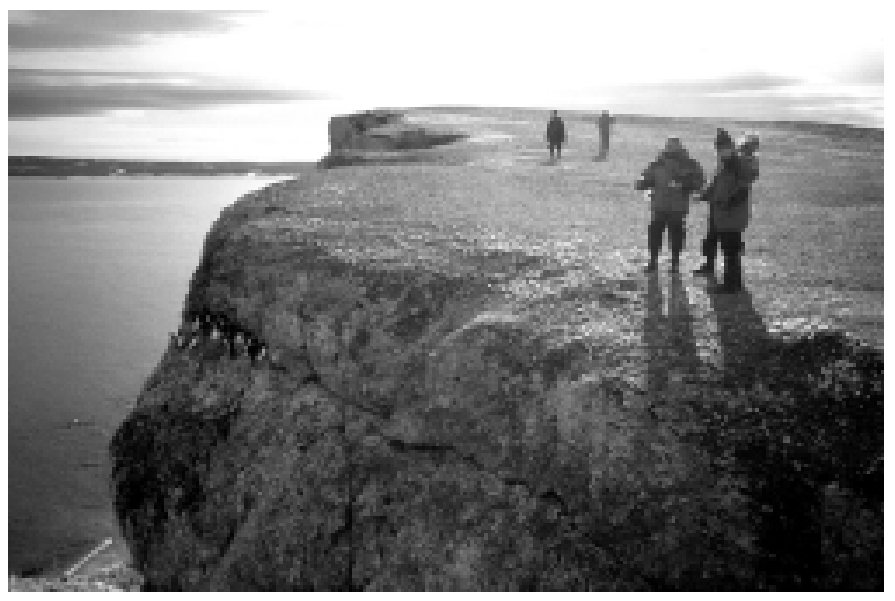

FIG. 5. View towards Cape Carlsen from the western Orange Island. Note birds (U. lomvia; murre) in the cliffs. Photo by D. Lubinski.

walrus, and reindeer. The coastline was searched for a double grave, possibly covered by a single large rock pile. Northern Novaya Zemlya is a nutrient-deficient arctic desert. Moss growths occur when phosphates are released, for example, by a bird carcass or whale bone. We inspected cairns and large moss patches with mine detectors (Vallon ML-1612B) and bomb locators (Vallon EL-1303 magnetometers) for buttons and other metal parts that might indicate the presence of a human body (Fig. 4). This region has a low tidal range $(<0.6 \mathrm{~m}$; Gorshkov, 1983). Relative sea level has lowered by $\sim 80 \mathrm{~cm}$ during the past 400 years (Zeeberg, 2001). Thus, the coastal features of 1597 have a similar appearance today. Permafrost would not have prevented burial, because drainage of these beaches is good and the gravel can be dug into.

Cairns, guri in Russian, are rock pilings usually less than $1 \mathrm{~m}$ high constructed by travelers, either to mark their presence, a message, or supplies, or to serve as navigational aids. Russian travelers left messages only at prearranged locations (Starokadomskiy, [1946] 1976: note 48). Cairns were not reported by the Dutch in 1594-98, and most of those encountered on northern Novaya Zemlya probably date from explorations after ca. 1860 , when the region north of $\sim 76^{\circ} \mathrm{N}$ became accessible in a warming, post-Little Ice Age climate (Zeeberg, 2001). A first-order age approximation for objects and landforms in the Arctic can be derived from lichen growth diameters. Lichen growth, which is directly related to mean summer temperature and precipitation, may have been limited by persistent snow cover during the Little Ice Age (Locke and Locke, 1977; Werner, 1990). Lichen (Rhizocarpon sp.) diameters of 30-40 $\mathrm{mm}$ have been established for blubber ovens and whaling graves from the mid-17th century on northwestern Spitsbergen (Werner, 1990, 1993). Lichens were not recorded on the Saved House, because the structure was destroyed after 1871. Low lichen growth rates are expected for northern Novaya Zemlya, which has a mean summer temperature of $2^{\circ} \mathrm{C}$ (Cape Zhelaniya), compared to $5^{\circ} \mathrm{C}$ for western Svalbard. 
On northern Novaya Zemlya, 400-year-old Rhizocarpon sp. lichens are probably $2.0-2.5 \mathrm{~cm}$ in diameter.

\section{RESULTS}

\section{Russian Results from Ivanov Bay and Cape Vil'kitsky}

Inspection of Novaya Zemlya's northern shores by D. Kravchenko between 1979 and 1982 was based on De Veer's account, translated into Russian by V.Yu. Vize (1936). Kravchenko $(1981,1983)$ identified two rock pilings on the beach of Ivanov Bay (Sites \#1 and \#2) and a rock piling at Cape Vil'kitsky (Site \#4) as possible burial sites:

[Site \#1] If Willem Barents and Claes Andriesz are buried in the coastal area, one should find their graves [in the vicinity of Cape Carlsen] near Cape Petrovski, which is on the coast of Ivanov Bay. [Here we located] a small cairn about the size of a man, covered by sizable boulders and quite damaged, partly collapsed by permafrost processes. Local seafarers used to construct similar cairns at obvious locations to serve as navigational markers. The present pile, however, was not at a cape, could not be seen from the sea, and must have served some other purpose.

[Site \#2] We found another small rock-pile grave on the coast of Ivanov Bay. A wooden pole, heavily eroded by winds, had been forced about $1.5 \mathrm{~m}$ into the ground. A Latin inscription could be partly read: it said "Bar" and, below that, "55" or "SS" (two fives are more likely). The shape of this second mound was less clear, except for a clear ring of soil about 2 or $3 \mathrm{~cm}$ high.

[Site \#4] [Barents and Andriesz] were buried on the coast. The grave on CapeVil'kitsky is probably theirs. Why would we assume that this is a foreign grave, not of Russian origin? First, Pomors never buried their dead in permafrost, because that would be too much effort. Second, the object displays a clear geometric form, an almost perfect rectangle of $2 \times 2.5 \mathrm{~m}$. It thus resembles a double grave. (Kravchenko 1981:101-117)

A third possible grave (Site \#3) at Ivanov Bay was discovered by Russian investigators in 1988.

\section{Orange Islands}

The geographical accuracy of De Veer's report of events between 16 June and 21 June 1597 is further confirmed by comparing his observations with the present situation. To collect eggs and melt drinking water, on 16 June the men visited the Orange Islands, which are two flat-topped rock columns jutting up conspicuously from the sea to $20-25 \mathrm{~m}$ asl (Fig. 5). These islands lie $3 \mathrm{~km}$ north of Cape Carlsen, Novaya Zemlya's northernmost cape $\left(77^{\circ} \mathrm{N}, 67^{\circ} 40^{\prime} \mathrm{E}\right)$. A group of islets $5 \mathrm{~km}$ east, called the "Lesser Orange
Islands," was visited by the Arctic schooner Willem Barents in 1884. It is likely that De Veer recognized only the larger Orange Islands for their distinct appearance. De Veer reported that the boats were unable to reach the beaches and instead were fastened to the belt of shore-ice surrounding the islands. The island provided driftwood, but it had no birds. Three men walked across the ice towards the other island, a distance of about $1.7 \mathrm{~km}$, where they collected eggs and caught three birds. A visit to the Orange Islands in 1998 showed that there are no birds on the eastern island, but a large colony of murres (Uria lomvia) occupies the $\sim 20 \mathrm{~m}$ high cliffs of the western island.

\section{Ice Cape}

Ice Cape is a generic name for the region between Inostrantsev Bay and Cape Varnek, which includes the calving margins of four outlet glaciers (Vera, Anna, Bunge, and Petersen). De Veer's account does not mention these impressive formations, but the accompanying map shows the increased density of sea ice around Ice Cape, which probably reflects iceberg calving (Fig. 1c). The map furthermore shows the track of the boats around this impassible area. Beaches and promontories between these glaciers were inspected by D. Kravchenko (1983) and G. Maat with J.J. Verlaan (Maat and Verlaan, 2001). On the northern cape of Anna Bay is a rock pile $3.5 \mathrm{~m}$ wide supporting a $2.4 \mathrm{~m}$ high pole. This pole has a sign with Cyrillic lettering "Dyagilev 1957." On the southern cape (Cape Otvazhnych) is a $0.6 \mathrm{~m}$ high, cone-shaped pole, which Maat and Verlaan (2001) identified as Kravchenko's Site \#2. The northwest side of this pole has been cut flat, and here was carvednot in Latin letters, as suggested by Kravchenko (1981, 1983), but in Cyrillic - BpR. Underneath this it reads 1955 and a Cyrillic $g$, for "year." This pole and a similar pole on the coast of Ivanov Bay likely reflect the activities of surveyors in 1955 and 1957.

The Dutch in 1597 may have landed between Cape Medvezhy and Inostrantsev Bay (Fig. 1b), although De Veer's text and map suggest that after leaving Cape Varnek, they first reached the coast at Bear Cape (the present Cape Vize). The coastline and escarpment between Cape Medvezhy (Cape Polar Bear) and Inostrantsev Bay were inspected in 1995 and 1998. A prominent, partly collapsed cairn was discovered on the northern beach of the innermost Inostrantsev Bay, with a smaller cairn on the adjacent $20 \mathrm{~m}$ high escarpment. This location, however, is unlikely to have been visited by the Dutch, because the extended Pavlov and Inostrantsev glaciers would have limited their access to this part of the bay.

\section{Coast of Ivanov Bay}

The first site identified by Kravchenko (Site \#1) is located on a $\sim 20 \mathrm{~m}$ high escarpment near Cape Petrovski (Fig. 3). On this location is a collapsed cairn, about $2 \mathrm{~m}$ across and $0.4 \mathrm{~m}$ high. A central depression suggests that 


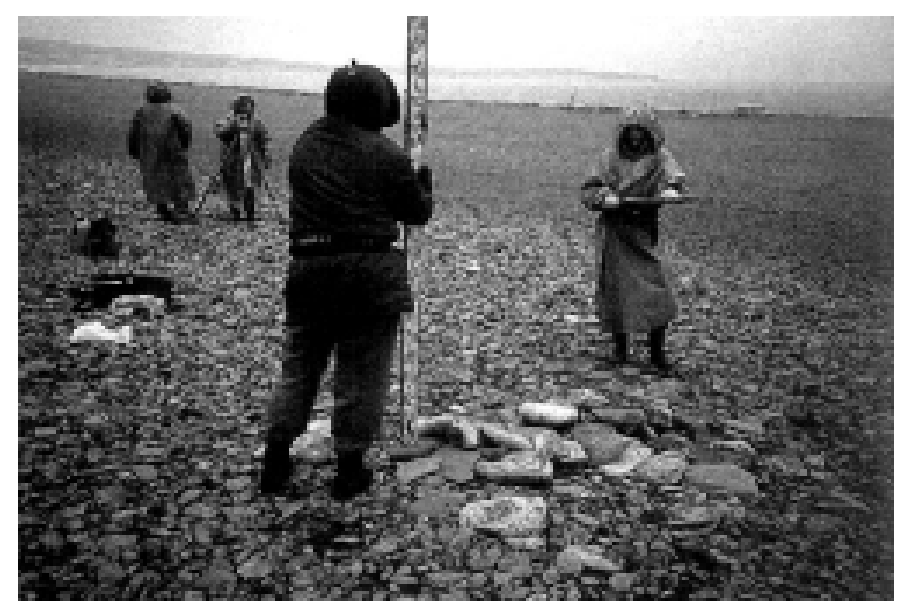

FIG. 6. Archaeological survey of a potential rock-pile grave (Site \#3) on the beach of Ivanov Bay. The structure in the background is a shelter erected by 1995 expedition (repaired and enforced in 1998). Photo by P.M. Floore.

this cairn may have supported a pole or a cross for navigational purposes (Salikov, 1997).

The second site (supposed Site \#2) is marked by a well dug-in driftwood pole on the beach of Ivanov Bay (Fig. 3). This pole, $1.1 \mathrm{~m}$ high and $25 \mathrm{~cm}$ in diameter, is $56 \mathrm{~m}$ inland from the high tide line. The top is cone-shaped, and a thick, modern wire-nail has been driven into the tip. A crude face was carved on the north side (Maat and Floore, 1997; Maat and Verlaan, 2001). On the escarpment about $100 \mathrm{~m}$ to the south are the remains of a camp, which, according to our Russian collaborators, was used by surveyors in the 1950s. An airphoto-based topographical map of north Novaya Zemlya was first published in 1952. Hence, in appears that this pole and a similar pole on the southern cape of Anna Bay (Cape Otvazhnych, $25 \mathrm{~km}$ west of Ivanov Bay) were used by surveyors in 1955-57 to calibrate elevations to sea level.

The third site identified in Ivanov Bay is a collapsed cairn on a $12.5-13.5 \mathrm{~m}$ high beach berm, about $400 \mathrm{~m}$ inland from the high tide line (Fig. 3). The SW-NE oriented structure covers $2 \times 1.6 \mathrm{~m}$ and is $\sim 0.5 \mathrm{~m}$ high (Fig. 6). The soil underneath it was excavated in 1995 to a depth of $0.1 \mathrm{~m}$ and found to be undisturbed. A trench dug to $0.7 \mathrm{~m}$ revealed an undisturbed stratification of beach gravel and $10 \mathrm{~cm}$ thick layers of silty sand. The excavation was backfilled and the stone configuration restored on the basis of drawings and chalk outlines that had been prepared before dismantling this cairn (Salikov, 1997).

\section{Cape Vil'kitsky}

A $1.2 \mathrm{~m}$ high cairn was identified on the southwestern side of Cape Vil'kitsky (Site \#4, Fig. 3), halfway between Cape Carlsen and Ivanov Bay. This cairn cannot be seen from a vessel at sea and, hence, was not erected as navigational aid. Mosses cover the southern and western sides of this monument. A drawing shows the cairn on top of a $2 \mathrm{~m}$ long and $1.8 \mathrm{~m}$ wide rectangular disturbance facing east. The surface of this rectangle has sagged, suggesting con-
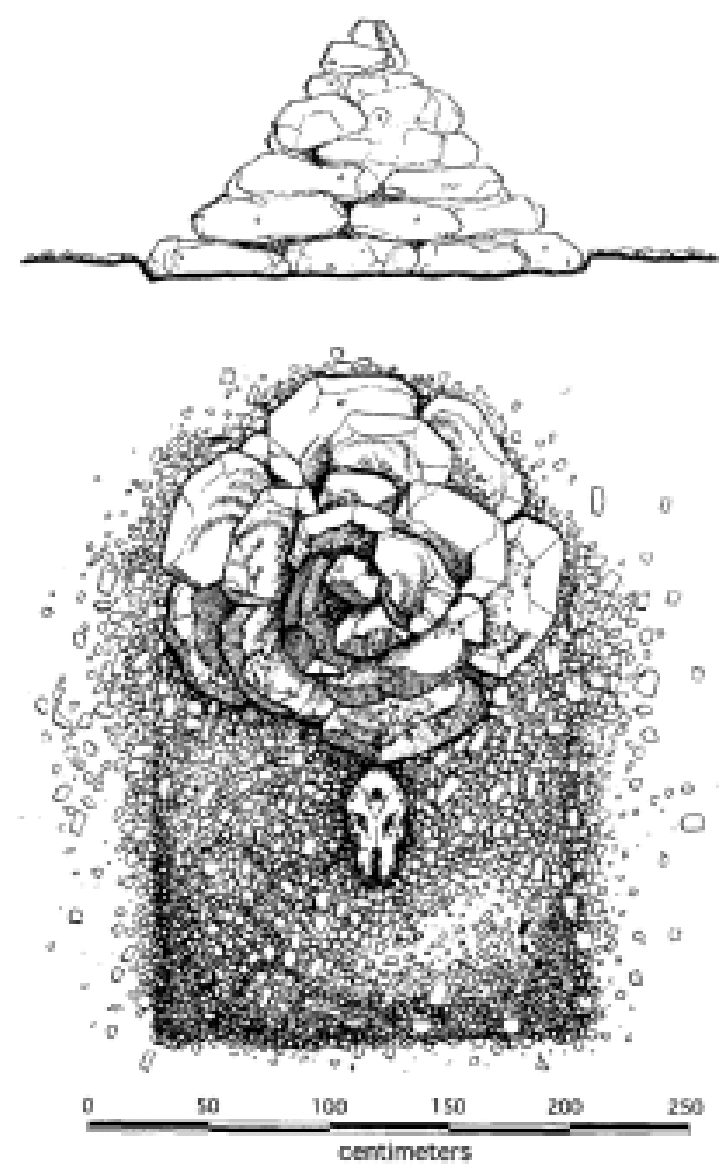

FIG. 7. Sketch by D. Kravchenko of a possible burial site on Cape Vilkitsky (Kravchenko, 1983). The site could not be located during a survey of this cape in 1998 (Maat and Verlaan, 2001).

solidation after digging (Fig. 7). The site was decorated by a bear skull, which reportedly has a perforation the size of a musket shot, carried by the Dutch in 1597 (Kravchenko, 1983). Cape Vil'kitsky was searched in 1998 , but the site was not located.

\section{Cape Varnek}

The Dutch on 17-18 June 1597 probably made landfall at Cape Varnek, because it protrudes into the sea $\sim 2.5 \mathrm{~km}$ compared to Ivanov Bay, which lies on its lee side and was probably filled with ice (Fig. 3). On the $5-20 \mathrm{~m}$ tall promontory are several cairns, but none of those is a rockpile grave. Adjacent to the cairn on Cape Varnek is a rusted fox trap, anchored by a log, reflecting visits by crew from polar station Cape Zhelaniya. The beach west of Cape Varnek is $100-800 \mathrm{~m}$ wide and $3 \mathrm{~km}$ long. This strandflat inclines to an escarpment at $10 \mathrm{~m}$ asl (Fig. 8). Modern driftwood (sawn timber logs; cf. Johansen, 1998), is scattered across the beach to an elevation of at least $5 \mathrm{~m}$ asl, reflecting exposure of the cape to the west-southwestern fetch across the Barents Sea and high storm run-up hundreds of meters inland. Thus, it is likely that Barents and 


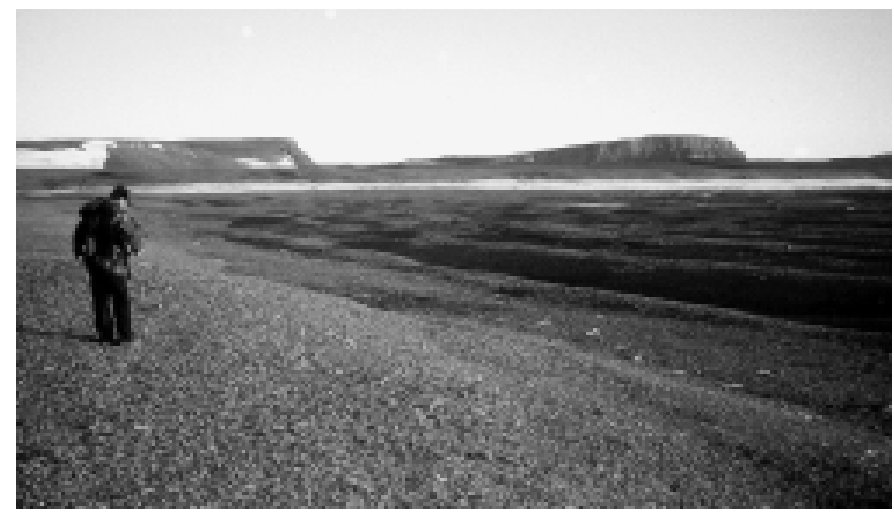

FIG. 8. Beach ridges $\sim 5 \mathrm{~m}$ asl and escarpment at Cape Varnek, the most probable location of Barents' and Andriesz' grave. Photo by J. Zeeberg.

Andriesz were buried on the beach of Cape Varnek, but this grave was destroyed during storm surges.

\section{CONCLUSIONS}

1. Willem Barents and one of his crew were probably buried in an improvised grave on northernmost Novaya Zemlya, in the area between the Petersen Glacier and Cape Carlsen. The Dutch probably made landfall in the vicinity of Cape Varnek.

2. Barents' grave cannot be found on Cape Varnek because of severe physical erosion of the beach by storm surges and retreat of snowbanks.

3. On the $3-30 \mathrm{~m}$ high escarpment that is traced along the northern coast, cairns (guri's) were found on many promontories. None of those had lichen growths that would indicate construction $\sim 400$ years ago $(>2 \mathrm{~cm}$, Rhizocarpon sp.) or the dimensions of a rock-pile grave.

4. The rock-pile graves identified by previous Russian research (Kravchenko, 1981, 1983) did not contain human remains or objects. We conclude that these are collapsed cairns. A pole allegedly inscribed "Bar... 55" and erroneously reported by Kravchenko on the coast of Ivanov Bay was located on Cape Otvazhnych and found to bear the Cyrillic inscription "BpR '55g."

5. Cairns were not reported by the Dutch in 1594-98, and most of those encountered on north Novaya Zemlya probably date from explorations after c. 1860, when the region north of $\sim 76^{\circ} \mathrm{N}$ became accessible in a warming post-Little Ice Age climate.

6. The historical record indicates that the Dutch measured distances in German miles of $6.3 \mathrm{~km}$, and applied classical trigonometry to calculate meridional distances, assuming 5400 German miles $(34020 \mathrm{~km})$ for the circumference of the earth.

\section{ACKNOWLEDGEMENTS}

This research was supported by the University of Amsterdam, Wegener Press, and National Science Foundation award OPP-
9796024 granted to Steve Forman (University of Illinois at Chicago). We gratefully acknowledge Pyotr Boyarsky (Heritage Institute, Moscow) and Vadim Starkov (Russian Academy of Sciences), for providing access to north NovayaZemlya in 1995 (R/V Ivan Kiriev) and 1998 (R/V Ivan Petrov), and the Arctic and Antarctic Research Institute (St. Petersburg), for providing access to Novaya Zemlya via Dikson in 1993.

Henk van Veen (Stichting Willem Barents, The Netherlands) was in charge of logistical arrangements in 1993 and 1995. G. Maat and P. Floore with Jevgeni Salikov and Konstantin Blinov studied cairns in the Ivanov Bay area in 1995. During the surveys in 1998, G. Maat was assisted by Jorrit-Jan Verlaan; and J.J. Zeeberg, by Dimitri Badyukov and David Lubinski (INSTAAR, University of Colorado at Boulder). Bomb locators and mine detectors were provided by the Explosive Ordnance Disposal branch of the Royal Dutch Air Force, and gear was provided by the Korps Mariniers of the Royal Dutch Navy.

\section{REFERENCES}

ARCTIC PILOT. 1959. Volume 1 (USSR). London: Hydrographic Department of the Admiralty.

ARNEBORG, J., HEINERMEIER, J., LYNNERUP, N., NIELSEN, H.L., RUD, N., and SVEINBJORNSDOTTIR, A.E. 1999. Change of diet of the Greenland Vikings determined from stable carbon isotope analysis and ${ }^{14} \mathrm{C}$ dating of their bones. Radiocarbon 41(2):157-168.

BEATTIE, O., and GEIGER, J. 1987. Frozen in time: The fate of the Franklin expedition. London: Bloomsbury.

BEKE, C.T., ed. 1853, 1876. The three voyages of William Barents to the Arctic Regions $(1594,1595$, and 1596), by Gerrit de Veer [1598]. Reprint of the 1609 edition (translation by A. Philip, 1607). London: Hakluyt Society.

BRAAT, J., GAWRONSKI, J.H.G., KIST, J.B., PUT, A. VAN DE, and SIGMOND, J.P., eds. 1998. Behouden uit het Behouden Huys. Catalog of objects from the Saved House. The Rijksmuseum collection, supplemented with Russian and Norwegian finds. Amsterdam: Bataafsche Leeuw. (In Dutch) $343 \mathrm{p}$.

DE VEER, G. [1598]. The three voyages of William Barents to the Arctic Regions (1594, 1595, and 1596). Reprint of the 1609 edition (in English translation by A. Philip, 1607) edited by C.T . Beke (1853, 1876). London: Hakluyt Society.

FLOORE, P.M., GAWRONSKI, J.H.G., HEFTING, O., and ZEEBERG, J.J. 1999. Nederlanders in de Straat van Magelhaes. Zoektocht naar de sporen van de overwintering van de vloot van Mahu en De Cordes in 1599. [Dutch in the Strait of Magellan. Search for traces of the wintering of the fleet of Mahu and De Cordes in 1599]. Amsterdam. (In Dutch and Spanish) $60 \mathrm{p}$.

GAWRONSKI, J.H.G. 1997. Trapped in wood and ice. A preliminary reconstruction of the Behouden Huys. In: Gawronski, J.H., and Boyarsky, P.V. Northbound with Barents. Amsterdam: Jan Mets. (In English and Russian) 77-86.

GORSHKOV, S.G., ed. 1983. World Ocean Atlas III, Arctic Ocean. Oxford: Pergamon Press. 184 p. 
HACQUEBORD, L. 1981. De eerste onderzoeksresultaten van het Smeerenburg-project. In: Hacquebord, L., and De Bok, R., eds. Spitsbergen $80^{\circ} \mathrm{N}$. Amsterdam: Elsevier. 130-159.

- 1995. In search of Het Behouden Huys: A survey of the remains of the house of Willem Barentsz on Novaya Zemlya. Arctic 48:248-256.

JOHANSEN, S. 1998. Origin of driftwood in north Norway and its relevance for transport routes of drift ice and pollution to the Barents Sea. Science of the Total Environment 231:201-255.

KIST, J.B. 1981. Het begin van het Smeerenburg-project. In: Hacquebord, L., and R. de Bok, R., eds. Spitsbergen $79^{\circ}$ NB. Amsterdam: Elsevier. 67-78.

KRAVCHENKO, D. 1981. Report of the Arctic Historical Complex Expedition (AKIE 1979) on the north-east coast of Novaya Zemlya (Ledyanya Gavan'). Netherlands-USSR Bulletin 34:6. (In Dutch, translated from Russian)

1983. Report of the Arctic Historical Complex Expedition, AKIE 1979-1982. Cultural Service and Regional Museum of the Archangelsk Oblast. (In Russian)

LINSCHOTEN, J.H. van. 1601. Voyage or navigation round by the north. (Voyage van bijnoorden om door de engte van Nassau (Straat Joegor) tot voorbij de rivier Oby, etc.) Enkhuizen. (In Dutch)

LOCKE, C.W., and LOCKE, W.W. 1977. Little Ice Age snow cover extent and paleoglaciation thresholds: North-central Baffin Island, NWT, Canada. Arctic and Alpine Research 9:291 -300.

MAAT, G.J.R. 1981. Human remains at the Dutch whaling stations on Spitsbergen. In: Van Holk, A.G.F., ed. Early European exploitation of the northern Atlantic 800-1700. Groningen: Arctisch Centrum. 213-217.

MAAT, G.J.R., and FLOORE, P.M. 1997. A search for Willem Barents in the Ivanov Bay area. In: Gawronski, J.H., and Boyarsky, P.V., eds. Northbound with Barents. Amsterdam: Jan Mets. 97-99.
MAAT, G.J.R., and VERLAAN, J.J. 2001. The search for Willem Barentsz. Report on the International Nova Zembla expedition 1998. 2nd ed. Barge's Anthropologica 4, Leiden University Medical Center. 22 p.

PILOT OF THE BARENTS SEA. 1995. Department of Navigation and Oceanography, Russian Ministry of Defense, St. Petersburg.

PFIRMAN, S.L., KOGELER, J.W., and RIGOR, I. 1997. Potential for rapid transport of contaminants from the Kara Sea. Science of the Total Environment 202:111-112.

SALIKOV, J.A. 1997. Following the signs of Pomors and Dutch seamen: Archaeological surveys in the Novaya Zemlya Region. In: Gawronski, J.H., and Boyarsky, P.V., eds. Northbound with Barents. Amsterdam: Jan Mets. 92-97.

STAROKADOMSKIY, L.M. 1946. Charting the Russian Northern Sea Route. Translated and edited by W. Barr, 1976. Montreal: McGill-Queen's University Press. 332 p.

VAN DER WERF, S.Y. 1998. Astronomical observations during Willem Barents's third voyage to the North (1596-97). Arctic 51:142-154.

VERHOEFF, J.M. 1983. De oude Nederlandse maten en gewichten. Amsterdam: Meertens Instituut.

VISE, V.YU. 1936. Barents Navigation (Diarum Nauticum) $1594-$ 1597. [Translation of De Veer, 1598] Leningrad. 308 p. (in Russian)

WERNER, A. 1990. Lichen growth rates for the northwest coast of Spitsbergen, Svalbard. Arctic and Alpine Research 22: $129-140$.

___ 1993. Holocene moraine chronology, Spitsbergen, Svalbard: Lichenometric evidence for multiple Neoglacial advances in the Arctic. The Holocene 3:128-137.

ZEEBERG, J.J. 2001. Climate and glacial history of the Novaya Zemlya Archipelago, Russian Arctic, with notes on the region's history of exploration. Amsterdam: Rozenberg Publishers. $176 \mathrm{p}$.

ZEEBERG, J.J., and FORMAN, S.L. 2001. Changes in glacier extent on north Novaya Zemlya in the twentieth century. The Holocene 11(2):165-179. 